\title{
. \\ WORLD FEDERATION OF PUBLIC HEALTH ASSOCIATIONS \\ WFPHA: World Federation of Public Health Associations
}

www.wfpha.org

Journal of Public Health Policy (2010) 31, 378-380. doi:10.1057/jphp.2010.26

The World Federation of Public Health Associations held its 44th Annual Meeting in Geneva on 16 May 2010. In his final speech to the WFPHA General Assembly, immediate Past-President, Dr Paulo Buss, reflected on 2008-2009. He discussed the Federation's most important challenges and accomplishments during the last 2 years of his presidency: its most difficult challenges included the worldwide financial crisis and the decline of international aid. Nonetheless, WFPHA accomplished significant advances. The Istanbul Congress was well attended with almost 2000 participants from 120 countries. Despite the threat of the $\mathrm{H} 1 \mathrm{~N} 1$ pandemic, WFPHA drafted and approved the Istanbul Declaration during the Congress. Having started as only a dream, WFPHA has established a small office in the 'capital of global health'. Led by Professor Bettina Borisch and Laetitia Bourquin, the office creates an important presence in Geneva, helping WFPHA to re-confirm its official relations with the World Health Organization (WHO). Dr Buss conveyed a message of optimism and confidence to member associations and his wishes for great success to Dr Ulrich Laaser as the new incoming President and Jim Chauvin as the new Vice-President/President-Elect.

The major outcomes of the Annual Meeting included revision of documents by the Executive Board and approval by the members of the General Assembly, as follows:

1. WHO/WFPHA Work Plan for 2010-2012

2. Treasurer's Report and Auditor

3. Approved Funding-Sponsorship Policy 
4. Proposed Changes to the By-Laws and Constitution

5. President's Strategy Program 2010-2012

More information on the meeting proceedings and full versions of the documents listed above will be posted on the WFPHA website (www.wfpha.org).

The newly constituted Policy Committee has defined three new goals in relation to the Federation's Strategic Plan. Goal 1 (Tobacco control) and 2 (Environmental impact on health) are based on the work of existing working groups. As the Executive Board defined goal 3 (Global Equity) during it's meeting, more discussions on the precise definition and a work plan for this topic will follow soon.

WFPHA's President, Professor Ulrich Laaser, has been meeting with members of the Ethiopian Public Health Association as well as local health officials and partners in the planning the upcoming Congress toll take place '22-27 April 2012' in Addis Ababa. For more information, please visit: http://www.etpha.org/2012.

The WFPHA is pleased to welcome Rebecca Bailey as the new liaison to the WHO, a public health and education specialist from the United States. She worked overseas for several years on health, development, and education projects in Asia, Africa, and Latin America before joining the WHO in Geneva in 1997. As a Technical Officer for Education and Training for the WHO Department of Child and Adolescent Health and Development, she developed alternative approaches including e-learning, in-service training in Integrated Management of Childhood IIIness (IMCl), and a process and set of teaching and learning materials for incorporating $\mathrm{IMCl}$ into the basic education of primary health-care providers. In 2007, she joined the WHO Department of Human Resources for Health in the Health Workforce Education and Production Team, where she is responsible for approaches to scaling up and transforming health workforce education and training, with a particular focus on countries with critical health workforce shortages.

The WFPHA office in Geneva has strengthened the WFPHA link with $\mathrm{WHO}$, and together the two organizations have prepared a new collaboration plan (2010-2012) and hold regular meetings (Borisch and Bourquin with Baily). This new collaboration is very promising; through it WFPHA has the opportunity to advance exciting topics related to Global Public Health Education.

For the past several years, the American Public Health Association has kindly supported and hosted the WFPHA Secretariat Office in Washington 
DC. As the Federation expands and its partnerships grow, the needs of the organization are also growing. The Secretariat functions and responsibilities have now moved from Washington DC to Geneva, based on mutual agreement to strategically position the Federation for closer collaboration with $\mathrm{WHO}$ and with other international organizations. Working together, the Washington office, the Geneva office, and the WFPHA Executive Board will soon draft and implement a transition plan. By early 2011, we expect the Geneva office to be fully operational. Professor Bettina Borisch and Laetitia Bourquin will head the office with much needed assistance of one additional person. The office will make new links with the member associations, as we inquire about each association's needs in order to respond to their expectations as well as possible.

The Geneva Office is looking forward to this new and exciting phase and we thank Vina Hulamm and Georges Benjamin for their continuing assistance to this transition.

Bettina Borisch and Laetitia Bourquin

Contact:

WFPHA Office

c/o Institute for Social and Preventive Medicine

University of Geneva

CMU, 1, rue Michel Servet

$\mathrm{CH}-1211$ Genève 4

Switzerland

E-mail: geneva@wfpha.ch

Website: www.wfpha.org 